\title{
THE SPECIFICS OF THE NEW STATE PROGRAM OF DEVELOPMENT OF THE MILITARY-INDUSTRIAL COMPLEX
}

Target indicators of the Military-Industrial Complex Development, a state program approved in May 2016 can hardly be regarded to be in compliance with declared objectives of the country's leadership and the Military-Industrial Commission in terms of diversification and defense conversion. The program's main objective is quantitative growth and not development targets. The total number of state programs for the military-industrial complex (MIC) is excessive and something is to be done about it to improve the situation.

On May 25, the Government Resolution on Approval of the MilitaryIndustrial Complex Development State Program ${ }^{1}$ which integrated measures earlier included in State Program No.16 of "Development of Industry and Upgrading of its Competitiveness" of Sub-Program No.5 of "The Accelerated Development of the Military-Industrial Complex of the Russian Federation" and the Federal Target Program (FTP) of "Development of the MilitaryIndustrial Complex in the 2011-2020 Period" ${ }^{2}$ was published. Along with the Resolution, an extract was published from the new state program to the extent that does not include state secret information and confidential information of restricted distribution, so it is almost impossible to get a comprehensive idea about goals, objectives, target indicators and the volume of budget funding of the program.

The amount of $\mathrm{Rb} 34,893 \mathrm{bn}$ specified in the published version of the state program as the volume of budget allocations was regarded by the mass media as explicitly insufficient enough ${ }^{3}$, which factor prompted the government on May 30 to make public the total volume of budget allocations (Rb $1,000,067$ trillion), classified subprograms and target indicators of the above state program ${ }^{4}$. The latest version of budget classification where the content of all the five subprograms is shown in such a detail that the main measures with specification of the MIC entities are provided gives an additional idea about the new $44^{\text {th }}$ state program in succession (hereinafter SP-44) 5 . With taking into account the published date, it is believed that SP-44 includes the following subprograms: 1. - "Motivation of Development of the Military-

1 Resolution No.425-8 of 16 May 2016 of the Government of the Russian Federation on Approval of the Development of the Military-Defense Complex State Program of the Russian Federation. URL: http://government.ru/media/files/iZ4uqvL9mUDskW9PchNt043CW0AuuYQN.pdf (date of application: 25.05.2016).

2 Approved in April 2014 and February 2012, respectively.

3 V. Mukhin. The Defense Industry Funding will be Modest // The Nezavisimaya Gazeta. 27 May 2016.

4 The meeting with Vice-Premiers: Verbatim records. Gorki, 30 May 2016. URL: http:// government.ru/news/23202/ (date of application: 30.05.2016).

5 Annex No.10 to Order No.90n of 20 June 2016 of the Ministry of Finance of the Russian Federation on Amendment of Instructions on the Procedure for Application of Budget Classification of the Russian Federation approved by Order No.65n of 1 July 2013 of the RF Minister of Finance, pp. 944-959. URL: http://minfin.ru/common/upload/library/2016/06/ main/prik90n_ot_200616_pril.zip (date of application: 11.07.2016). 
Defense Complex", 2. - Federal Target Program "Development of the MilitaryDefense Complex of the Russian Federation in the 2011-2020 Period", 3. "Import Substitution and Ensuring of Development of the Military-Industrial Complex", 4. - "Development and Organization of Production of Strategic Materials for Ensuring Manufacturing of Products for Military Purposes" and 5. - "Research in the Interests of Development of Industrial Technologies for Production of Armament and Military and Special Equipment".

The volume of budget funding of the open part of the first subprogram (alias the open part of budget allocations for the entire SP-44) in the 2016-2020 period increased by $\mathrm{Rb} 13,727 \mathrm{bn}$ or $65 \%$ as compared to respective open allocations for the $5^{\text {th }}$ subprogram of SP-16. At the same time, it can be supposed that budget allocations for SP-44 in general in the 2016-2020 period remained at the earlier planned level for the Federal Target Program (FTP) "Development of the Military-Industrial Complex of the Russian Federation in the 2016-2020 Period" (identified as FTP No.1 in the documents of the Ministry of Finance of the Russian Federation) for which it was envisaged to allocate from the federal budget in the 2012-2020 period Rb 1.8 trillion $^{1}$, that is, on average $\mathrm{Rb} 200 \mathrm{bn}$ annually. Initially, at the stage of development of the program it was expected to allocate half the size of budget funding volume ${ }^{2}$ for that FTP.

For the 2016-2020 period, general program indicators (Annex No.1 to Part No.1 of SP-44) utilize as a statistical base the level attained in 2014 instead of 2015, which practice is inadmissible in program documents. Evidently, it is for that reason the expected index of MIC industrial production of $119 \%$ in 2016 happens to be abnormally low year on year (105.4\% with taking into account as was declared a $12.9 \%$ growth in 2015) as compared to the average annual index of $109.7 \%$ in that period. Due to neglect of the architects of the program, a $80 \%$ MIC output industrial growth specified on page 2 of the text part of the program against the level of 2014 is not ensured by the index for 2020 on page 1 of Annex No.1 to the open part of SP-44 where the industrial production index of $174.6 \%$ is specified; with relevant rounding-off there is growth of $70 \%$ and not $80 \%$.

Generally, the value of that target index for 2020 in the new SP-44 as compared to $2015(154.7 \%)$ is in line with relevant target indicators of the $5^{\text {th }}$ subprogram of SP-16 and FTP-1: $142.6 \%$ and 1.5 times, respectively ${ }^{3}$. However, such an emphasis on quantitative growth in target indices of SP-44 cannot but raise doubts as despite the fact that the MIC industrial production index in 2015 amounted to $157.5 \%$ against the level of 2011 instead of $180 \%$, the share of modern samples of armament and military equipment in the armed forces of the Russian Federation rose to $47.2 \%$, having exceeded, as it was earlier stated, by $50 \%$ the planned index of the state armament program in $2015^{4}$. It

1 Verbatim records of the State Duma on 28 February 2012. URL: http://transcript.duma. gov.ru/node/3583/ (date of application: 12.07.2016).

2 The President approved the Guidelines for Russia's Policy of MIC Development till 2020 and Beyond; Verbatim records. Gorki, 19 March 2010. URL: http://kremlin.ru/events/president/news/7146 (date of application: 12 July 2016).

3 Page 9 of Annex No.3 to SP-16. URL: http://government.ru/media/files/1gqVAlrW8Nw. pdf (date of application: 12.07.2016); Rogozin: The output industrial volume of the Russian MIC will grow 4 times over by 2030. // RIA Novosti. 2 October 2012. URL: http://ria.ru/ defense_safety/20121002/764579539.html (date of application: 12.07.2016).

4 Defense Industry Failed to Underpin the Economy // Russian Economic Development. 2016. No. 5. P. 51. 
is believed that the program document approved in May 2016 should at least take into account risks related to creation of excessive production capacities in the MIC; indeed, as early as April the Russian leadership warned industrialists about the forthcoming reduction of procurement of weapons and military equipment starting from 2018 and the need to get prepared to defense conversion and diversification of the defense industry production ${ }^{1}$.

In this context, one cannot but pay attention to such a target indicator as the index of civilian production in the MIC of the $1^{\text {st }}$ subprogram of SP-44 which index in accordance with the data on page 2 of Annex No.1 to Part 1 of SP-44 should grow on average by 5.1\% annually in the 2016-2020 period against $9.7 \%$ for the MIC production as a whole and amount to $128.3 \%$ in 2020 against the 2015 level. The shown planned lag in MIC civilian production output growth calls into question the achievement of the goal set by the senior management of the Military-Industrial Commission, that is, to achieve "50/50 output of civilian and military-purpose production" - if one proceeds from the fact that "at present the volume of output of civilian production at MIC enterprises amounts to $45 \%^{\prime \prime}{ }^{3}$, then in future, by the end of 2020 , provided that the planned indicators of MIC industrial output growth have been met, it will fall to $38 \%$.

In the new SP-44, it is envisaged to put into operation 929 new production facilities, that is, on average 185 a year. ${ }^{4}$ As it is known, last year MIC entities commissioned 37 projects out of 368 projects where capital development was under way, that is, $10 \%{ }^{5}$. According to the data of the RF Accounts Chamber, last year in the radio-electronic industry alone deadlines for commissioning of 20 projects (only 5 projects were put into operation) were broken, while 57 projects in the Russian industry in general failed to be commissioned ${ }^{6}$. Considering the above, the SP-44 plans to put into operation new projects in the 2016-2020 period appear not quite realistic and even counterproductive due to the above cuts in procurement of weapons and military equipment from 2018. No secret, in reality decisions on modernization are postponed among other things due to growing volumes of the state defense order; MIC entities simply lack resources to carry out modernization projects ${ }^{7}$.

Certainly, one may believe that responsibility of federal executive officials will help ensure quality fulfilment of one or another state program ${ }^{8}$, however, the above analysis of some SP-44 indicators proves existence of state programs' general disadvantages specified on May 25 in the report by E. Elin,

1 The Congress of the Union of Engineering Workers of Russia. URL: http://kremlin.ru/ events/president/news/51746 (date of application: 19.04.2016).

2 Over $20 \%$ of the MIC production is exported, says Rogozin // RIA Novosti. 2 October 2012. URL: http://ria.ru/defense_safety/20121002/764571659.html (date of application: 12.07.2016).

3 A. Vaganov. The Defense Industry in Southern Urals Concentrated its Efforts on Cybernetics // Vecherny Chelyabinsk. 25 May 2016. URL: http://vecherka.su/articles/news/120376/ (date of application: 12.07.2016).

4 Meeting with Vice-Premiers.

5 The Military-Industrial Complex: Some Important Results and Indicators in 2015. URL: http://government.ru/info/22714/ (date of application: 12.07.2016).

6 Verbatim records of the meeting of the State Duma on 20 April 2016. URL: http://transcript.duma.gov.ru/node/4466/ (date of application: 12.07.2016).

7 A. Morozova and A Arseniev. The USSR Holds Hard // Novy Kompanion. 21 June 2016. URL: https://www.newsko.ru/articles/nk-3236878.html (date of application: 12.07.2016).

8 Meeting of the Government: Verbatim records. Moscow, 7 July 2016. URL: http://government.ru/news/23676/ (date of application: 12.07.2016). 
Deputy Minister of Economic Development to the Government as follows: 1) "goals, objectives and target indicators declared in state programs fail largely to agree with one another"; 2) "there is no distribution of responsibility and rights, such a distribution is not established legislatively"; 3) "at present the number of state programs is excessive. Their goals are largely similar or overlap. So, it would be expedient to consider the option of optimizing the number of state programs"1. The previous statement is particularly topical for the MIC where apart from the new SP-44 they carry out from 2014 SP-17 "Development of the Aircraft Industry in 2013-2015 Period", SP-18 "Development of Shipbuilding and Equipment for Development of Offshore Fields in 2013-2030 Period" and SP-19 "Development of Electronic and RadioElectronic Industry in the 2013-2025 Period".

1 The meeting of the Government: Verbatim records. Moscow, 26 May 2016. URL: http:// government.ru/news/23181/(date of application: 12.07.2016). 